\title{
Belgeo
}

Revue belge de géographie

$1-2 \mid 2012$

Inaugural issue

\section{Paradigm change in regional policy : towards smart specialisation? Lessons from Flanders (Belgium)}

Changement de paradigme dans la politique régionale : vers une spécialisation intelligente? Les leçons de la Flandre (Belgique)

Ties Vanthillo and Ann Verhetsel

\section{OpenEdition}

\section{Journals}

\section{Electronic version}

URL: http://journals.openedition.org/belgeo/7083

DOI: 10.4000/belgeo.7083

ISSN: 2294-9135

\section{Publisher:}

National Committee of Geography of Belgium, Société Royale Belge de Géographie

\section{Electronic reference}

Ties Vanthillo and Ann Verhetsel, « Paradigm change in regional policy : towards smart

specialisation ? Lessons from Flanders (Belgium) », Belgeo [Online], 1-2 | 2012, Online since 04 December 2012, connection on 19 April 2019. URL : http://journals.openedition.org/belgeo/7083 ; DOI : 10.4000/belgeo.7083

This text was automatically generated on 19 April 2019

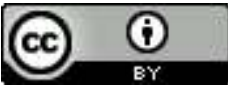

Belgeo est mis à disposition selon les termes de la licence Creative Commons Attribution 4.0 International. 


\section{Paradigm change in regional policy : towards smart specialisation? Lessons from Flanders (Belgium)}

Changement de paradigme dans la politique régionale : vers une spécialisation intelligente? Les leçons de la Flandre (Belgique)

Ties Vanthillo and Ann Verhetsel

\section{Introduction}

1 Since the 1980s scholars are looking for new approaches for local and regional development. The traditional growth and development theories could no longer explain the growth patterns of the 1980s and 1990s. A new approach emerged on how economic development takes place and how it relates to economic geography (Albrechts \& Swyngedouw, 1989 ; Barca, McCann \& Rodriguez-Pose, 2012 ; Capello \& Nijkamp, 2009). A theoretical transformation stressed the importance of aspects as human capital and innovation (endogenous growth theory), agglomeration and distance (new economic geography) and institutions (institutional economics). Furthermore, globalization spurred the importance of local specificities and material and non-material assets upon which the competitiveness of regions is based (Capello \& Nijkamp, 2009; Rodriguez-Pose \& Crescenzi, 2008).

2 The past 30 years can be seen as a difficult adjustment period for many European countries. With few exceptions, governments faced low rates of economic growth, high youth and long-term unemployment figures and regionally-concentrated economic development problems for instance in old-industrial areas, peripheral regions and innercities. At the same time governments also had to keep their economic sectors, ranging from traditional agriculture to high-tech industrial sectors and knowledge intensive business services, competitive in a globalized production environment (Bachtler, Wishlade \& Yuill, 2003; Barca, 2009). Some key features of the current globalization 
processes are relevant in studying regional policy development (Barca et al., 2012). Furthermore profound technological and institutional changes reshaped the competitive advantage of regions. These changes have drawn attention to the importance of localities for economic growth and the significance of "proximity" in the location of economic activity (Boschma, 2005 ; Rodriguez-Pose \& Crescenzi, 2008). It is generally accepted that "global city-regions" play a critical role in the generation of economic growth (McCann, 2008). But growth occurs across different kind of regions, also rural-ones, as the OECD study "How regions grow" indicates (OECD, 2009).

3 Consequently it appears that due to the changing role of "the region" in economic development, policies targeted towards regions underwent significant changes in objectives, geographical scope, governance and policy instruments (OECD, 2010). This paper challenges three main questions related to recent changes in regional policy. Firstly, what are the fundamental characteristics of the "old" regional policies? Secondly, did the "old" paradigm evolve into a new paradigm of regional policy? And if yes, how did these changes materialized and what characteristics where affected? Lastly, we consider how these changes were integrated in Flemish regional policies.

4 The paper is organized as follows. The first section gives an overview of the main characteristics of the old paradigm of regional policy and gives an overview of recent evolutions in policy characteristics. Answers to the research questions are provided by a review of the relevant literature. The second section is an empirical application of the framework that was developed in the first part of the paper. We use this framework to appreciate the evolution of Flemish regional policy. Therefore we employed an extensive literature review on the one hand, on the other hand we observed recent Flemish regional policy through policy documents.

\section{Paradigm shift in regional policy : from top-down to "place-based"}

5 The old paradigm of regional policy centered on top-down decision making by the central government or external agencies, while largely ignoring mixed, integrated and/or bottom-up approaches (Barca et al., 2012; Wolfe, 2011). In European countries the key elements of regional development policy of the old paradigm were based on infrastructure-driven projects like roads, railways, port infrastructure and sanitation in lagging and peripheral regions, creation of employment through state-aid-based industrialization and inward investment strategies aimed at supporting and attracting subsidiaries of leading international firms. These policy elements had a specific appeal to decision makers by their simplicity, tangibility and popularity (Bachtler \& Yuill, 2001).

6 The limits of traditional development policies, based on 1950s growth and development theories (e.g. Vanneste, 1967), became clear in the 1970s and 1980s (Buyst, 2012; Heremans, 1983; Wolfe, 2011). In general, regional development policies lacked coherence, with limited or no connection between spending on regional policy and the regional allocation of spending in other policy fields. Government departments created sectoral development programs which included little integration of instruments or coordination across policy fields (Heremans, 1983; Wolfe, 2011). Furthermore, the same solutions were applied to similar problems in different places without considering the specificity of the wider regional and local context (Barca et al., 2012). According to various 
authors, the "top-down regional development approach" had not been very effective in fulfilling the main objectives of regional policy, namely to address the concentrations of unemployment, to improve the economic situation of regions and to reduce disparities within and between countries (De Brabander, Vervoort \& Witlox, 1992 ; Heremans, 1983 ; OECD, 2009 ; Tödtling, 2010). State aid and industrial intervention in declining industries, "lame ducks" and big projects resulted in unbalanced policies, deterioration of industrial regions and the further economic marginalization of many peripheral and rural regions (see e.g. Grabher, 1993 on the Ruhr-region ; Hassink \& Shin, 2005).

7 As a counter-thesis to the "top-down regional development approach", national and regional governments slowly adapted to the growing complexity of regional issues (Hassink \& Klaerding, 2011 ; Lagendijk, 2011 ; Tödtling, 2010). In 2009 and 2010 a series of highly influential reports on regional development policy intervention were published by the OECD (OECD, 2009), the European Commission (Barca, 2009), the World Bank (World Bank, 2009) and the Latin American development bank Corporacion Andina de Fomento (CAF, 2010). Barca et al. (2012, p. 138) point out that these reports on development strategies are lame ducks"likely to reflect a collective reaction to the growing unease with the way development policies were conducted and their consequences".

8 The reports show a highly dynamic debate on regional policy which is divided in two radically different views (Barca et al., 2012 ; Pike, Rodríguez-Pose \& Tomaney, 2010). On the one hand a "spatially blind" idea of regional development policy, with an emphasis on the agglomeration and spillover benefits arising from the geographical concentration of growth (see e.g. World Bank, 2009). On the other hand a "place-based" approach that assumes that geographical context, in terms of institutional, cultural and social characteristics, matters. Furthermore it focuses on the issue of local knowledge in policy intervention and the role of institutions (see for a discussion e.g. Garcilazo, Martins \& Tompson, 2010 ; Gill, 2010). In this paper, we will focus on the latter approach. The "place-based" approach has emerged as the most influential in the thinking towards the future of regional development and cohesion policy in the European Union (DG Regional Policy, 2011; Wolfe, 2011).

9 Three interrelated drivers are seen to spur these new developments in regional policy (Bachtler et al., 2003; Barca et al., 2012). Firstly, a growing recognition that because of regional specificities and complexities policies need to be designed and shaped at the regional level itself (Lagendijk, 2011). This recognition has to be seen in relation to globalization processes which made development more localized and complex. Globalization unveiled the importance of local specificities and assets upon which the competitiveness of regions is based. For example the quality of the regional human capital base, the development of regional innovation policies, the presence of networks and clusters and the availability of specific knowledge infrastructure (Capello \& Nijkamp, 2009 ; Rodriguez-Pose \& Crescenzi, 2008).

10 Secondly, resulting from a diverse mix of social, cultural, economic and political factors, there is a growing trend of decentralization of different competences related to development fields (e.g. research policy, innovation policy, regional development policy) in European countries (OECD, 2010). Where initially the regional level adapted national policies and instruments, individual regions in various member states now have strengthened capabilities for tailor-made policies and they have more weight in regional programming and policy coordination (Bachtler et al., 2003 ; Lagendijk, 2011). 
11 Thirdly, the influence of EU policies played a key role in developing more strategic methods of facilitating regional economic development (Manzella \& Mendez, 2009; Raines, 2001). The program of regional development was first introduced in 1975 and has since then undergone a continuous process of change and evolution, although the framework of European regional policy remains very top-down oriented (Cabus, 2002 ; Wolfe, 2011). Since the end of the 1980s, the design and implementation of European regional policy provided a highly appropriate platform to experiment with programs and projects that targeted competitiveness issues besides cohesion (Tödtling, 2010). Moreover, it enhanced bottom-up development by fostering local partnerships of organizations to design their own programs (Cabus, 2002).

\section{A new paradigm of regional policy}

Bachtler and Yuill (2001) make mention of a shift in the paradigm of regional policy. In a 2010-report the OECD (2010) endorses Bachtler and Yuill's view and argues empirically that there is widespread evidence of an identifiable paradigm shift which involves new objectives, new geographical scope, new governance and new policy instruments for regional development. Table 1 gives an overview of this paradigm shift through ten characteristics.

13 The "new paradigm of regional policy" is "place-based, multi-level, innovative, and geared to different types of regions" (OECD, 2009; Wintjes \& Hollanders, 2010). According to Barca (2009) a place-based development approach should be aimed at institutional building and strengthening, improving accessibility to goods, services and information and to promote innovation and entrepreneurship. Furthermore essential features of the approach are : tailoring interventions to specific contexts and to their spatial linkages, and eliciting and aggregating the knowledge and preferences of local actors. A context-specific approach is needed while targeting the endogenous local assets and knowledge. As mentioned, the main objectives of regional policy in the old paradigm were the promotion of increased investment, creation of employment en the provision of infrastructures for economic development (Bachtler et al., 2001). We clearly see an evolution in the conceptual basis of development policies from regional attributes like production costs, availability of workers and infrastructure towards regional capabilities who stress the presence of an innovative milieu, clusters and interregional networks. Currently the focus shifts towards competitiveness issues like innovation, networking, quality of human capital and entrepreneurship. 
Table 1. Paradigm shift of regional development policy.

\begin{tabular}{|c|c|c|}
\hline & Old/classic paradigm & New/modern paradigm \\
\hline Conceptual basis & $\begin{array}{l}\text { Industrial location theories, } \\
\text { key factors are regional attributes } \\
\text { e.g. production costs, availability of workers }\end{array}$ & $\begin{array}{l}\text { Learning region theories, } \\
\text { key factors are regional capabilities } \\
\text { e.g. innovative milieux, clusters, networks }\end{array}$ \\
\hline $\begin{array}{l}\text { Aim(s) } \\
\text { Objectives }\end{array}$ & Equity through balanced regional development & $\begin{array}{l}\text { Increased competitiveness and equity } \\
\text { e.g. entrepreneurship, innovation }\end{array}$ \\
\hline $\begin{array}{l}\text { General policy } \\
\text { framework }\end{array}$ & $\begin{array}{c}\text { Compensating temporarily for location disadvantages } \\
\text { of lagging regions, } \\
\text { responding to shocks (e.g. industrial decline) } \\
\rightarrow \rightarrow \text { reactive to problems }\end{array}$ & $\begin{array}{l}\text { Tapping underutilised potential in all regions enhancing } \\
\text { regional competitiveness through regional and strategic } \\
\text { programming (e.g. smart specialization strategies) } \\
\text {-> proactive for potential }\end{array}$ \\
\hline Sphere of action & $\begin{array}{l}\text { Sectoral approach with a limited set of sectors } \\
\quad->\text { narrow (economic/industrial policies) }\end{array}$ & $\begin{array}{c}\text { Integrated and comprehensive development projects } \\
\text { with wider policy coverage }--\rightarrow \text { broad (integrated } \\
\text { development projects) }\end{array}$ \\
\hline $\begin{array}{l}\text { Spatial } \\
\text { orientation }\end{array}$ & $\begin{array}{c}\text { Targeted at lagging regions, within administrative } \\
\text { areas }\end{array}$ & $\begin{array}{l}\text { All-region focus, with orientation towards functional } \\
\text { economic areas }\end{array}$ \\
\hline Approach & One-size-fits-all approach & Context-specific approach (place-based approach) \\
\hline Focus & Exogenous investments and transfers & Endogenous local assets and knowledge \\
\hline Instruments & $\begin{array}{l}\text { Incentive scheme with subsidies and state aid, with } \\
\text { focus on hard infrastructure and business aid (often } \\
\text { to individual firms) }\end{array}$ & $\begin{array}{c}\text { Development programme with mixed investments for } \\
\text { soft and hard capital e.g. business environment, labour } \\
\text { market, infrastructure }\end{array}$ \\
\hline $\begin{array}{l}\text { Actors } \\
\text { Organisation }\end{array}$ & Top down policy development by central government & $\begin{array}{l}\text { Collective policy development by different levels of } \\
\text { government and various stakeholders (public, private, } \\
\text { NGOs) }\end{array}$ \\
\hline $\begin{array}{l}\text { Evaluation } \\
\text { /Outcomes }\end{array}$ & Ex post evaluation, measurable outcomes & $\begin{array}{c}\text { Ex ante, interim, ex post evaluation with difficulties to } \\
\text { measure outcomes }\end{array}$ \\
\hline
\end{tabular}

SOURCE : REVISION BY AUTHORS BASED ON OECD, 2008, P. 13 ; BACHTLER, 2001, P. 12.

14 As economic development shows a significant degree of spatial variability, regional policy focuses in all its forms on the problem of differential spatial development (Bachtler et al., 2003 ; OECD, 2009; Wintjes \& Hollanders, 2010). The debate on the objectives of regional policy is often between the traditional dichotomy of efficiency versus equity objectives. Barca $(2009$, p. 17) defines the dichotomy as follows: "Efficiency is about realizing the full utilization of the potential of every place or region. Equity is about ensuring equal opportunities for individuals irrespective of where they live". In the case of the European Union, the underlying tension between efficiency and equity can also be found in its regional policy. Since the beginning of the 1990s, the debate reconfigured between promoting international competitiveness and innovation and facilitating the convergence of individual member states and regions. The issue of convergence between (and within) lagging and core regions became more and more important with the recent enlargements of the European Union to 27 member states (Dogaru, Van Oort \& Thissen, 2011 ; Thissen \& Van Oort, 2010). Furthermore, in the Lisbon Treaty is stated that member states should "promote economic, social and territorial cohesion" (European Union, 2007). This explicitly recognizes territorial cohesion as a fundamental objective of the European Union. The Treaty implies that territory matters and that regional policy should be embedded in the broader framework of the Europe 2020 Strategy. Moreover, consideration is needed to the territorial impact of European policies (DG Regional Policy, 2011).

Furthermore recent work stresses the importance and need of joint-up approaches to regional development. Crescenzi \& Rodrigues-Pose (2011, p. 779) argue that: "increasing constraints in terms of public finance have emphasized efficiency considerations in top-down policies while increasing interconnectedness between local areas (and their communities) has 
favoured local actors' awareness of the impact of external conditions on local performance, making coordination between different policy actions and the reconciliation of top-down and bottom-up development policies increasingly relevant and necessary". Related to coordination, various authors point to the importance of multi-level governance to support regional development. There is a growing recognition that different interdependencies between levels of government exist (Charbit, 2011; Hooghe, Marks \& Schakel, 2010). National and supranational levels of government work increasingly together with local and regional levels to improve coordination and the implementation of commonly agreed goals and objectives. Moreover, the responsibility for policy design and implementation is allocated among different levels of government. This approach takes account of the perspectives of key regional actors with significant local interests. Next to that, within the regional policy field, the growing proliferation of actors can challenge issues of internal coherence (Bachtler et al., 2001 ; Tubex, Voets \& De Rynck, 2005).

Next to a move from cohesion towards competitiveness considerations and from topdown government to multi-level governance there is a trend towards policy integration. This trend is not only visible in European policies, also regions are working on the stronger alignment of regional, industrial and research policies (Lagendijk, 2011). Since the 1980s, innovation features more and more in regional development policies. The emergence and development of "cluster" approaches strongly intertwined industrial and regional policy. This could be illustrated with the example of the "Peaks in the Delta"program in the Netherlands or the "Pôles de Compétitivité"-approach in France. Furthermore, the importance of technology and innovation connected research policy to "place based" innovation approaches (Soete, 2009 ; McCann et al., 2011).

In the current debate on the future of the Science, Technology and Innovation (STI) and regional policies of the European Union the concept of "smart specialisation" has gained significant political and analytical importance (European Commission, 2010 ; McCann et al., 2011). According to the European Commission, smart specialisation strategies lead to a more comprehensive set of development objectives : "tapping under-utilised potential in all regions for enhancing regional competitiveness" (OECD, 2009). Rather than focusing on the dichotomy between convergence and competitiveness these strategies would enhance greater regional specialisation and cooperation.

There is a tendency for countries and regions to choose the same priorities. They all strive to become a hotspot in biotechnology, nanotechnology or information and communication technology (ICT) by hosting clusters of excellence, incubators, science parks and world class research hubs (Foray, 2009; Lagendijk, 2011). Foray (2009, p. 16) argues that this leads to the collection of subcritical systems: "all doing more or less the same thing, systems which are unattractive and thus cannot play in the arena of the world localization tournament". In the context of the European Research Area (ERA) and STI policy Foray (2009, p. 17) explicitly mentions not to "further increase polarization phenomena : scientific densification for some regions, 'desertification' for many others". But "to reconcile unrestricted agglomeration processes with a relatively balanced distribution of research capabilities across Europe" (McCann \& Ortega-Argiles, 2011 p. 7). Foray (2009) introduced the concept of "smart specialisation". He argues that regions should "particularise themselves" and develop an original strategic vision. Various authors make a case for smart specialisation strategies in the light of place-based regional policies (see Foray, 2011 ; McCann \& Ortega-Argiles, 2011 ; Wintjes \& Hollanders, 2010). 
Some authors claim that the concept of smart specialisation remains somewhat vague (Walendowski, 2011) and poses major challenges towards practical development (Lagendijk, 2011). Also McCann \& Ortega-Argiles (2011) argue that the application of the original sectoral logic of smart specialisation, as proposed by Foray (2009), is problematic. They claim however that with a place-based approach and some key issues in economic geography the concept could be applied for regional policy. Following the spatial smart specialisation logic, strategies should focus on the embeddedness of the existing local industries, meaning a further specialisation of the industrial structure. Building on theories of "related variety", McCann et al. (2011) argue that this would not necessarily increase the vulnerability of the region to external shocks or reduce the possibilities for knowledge spillovers. Regions should therefore develop an economic strategy that enhances the diversification into technologies which are closely related to the existing dominant technologies and build further on the regional embeddedness of the existing local industries. Furthermore, McCann et al. (2011) proposes to translate the connectedness argument of Foray (2009) in connectivity. This concept offers a more workable spatial-regional term with sufficient theoretical underpinnings than the sectoral way of thinking of Foray (2009). Policies should therefore also focus on linkages between regions. A view on the inter-regional innovation system is therefore important.

The European Commission initiated a platform to support regions in their efforts to set up these strategies. The Smart Specialisation Platform defines smart specialisation strategies as "regional research and innovation strategies that are integrated, place-based economic transformation agendas that do five important things:

- They focus policy support and investments on key national/regional priorities, challenges and needs for knowledge-based development.

- They build on each region's strengths, competitive advantages and potential for excellence.

- They support technological as well as practice-based innovation and aim to stimulate private sector investment.

- They get stakeholders fully involved and encourage innovation and experimentation.

- They are evidence-based and include sound monitoring and evaluation systems."

21 The concept of smart specialisation puts forward policy integration along both horizontal lines (between regional, industrial and research policies) and vertical lines (multilevel governance) (Lagendijk, 2011). The European Commission (2010) notes that: "smart specialisation strategies can also be a key element in developing multi-level governance for integrated innovation policies. Moreover they have to be closely linked with other policy domains and require an understanding of regional strengths relative to other regions". Furthermore, the European Commission is in the process of aligning the place-based approach within the broader framework of the "Innovation Union" (European Commission, 2010; Wolfe, 2011). A communication of the European Commission (2010, p. 6) on the role of Regional Policy to contribute to smart growth and the flagship initiative "Innovation Union" states that: "regional governments should, accordingly, develop smart specialisation strategies to maximise the impact of Regional Policy in combination with other Union policies". Moreover, in the European Commission's proposal on the next round of regional funding, the presence of a smart specialisation strategy is an ex-ante conditionality for regions with regard to the European Regional Development Fund (ERDF) in 2014-2020 (Foray et al., 2011). 


\section{Regional policy in Flanders. The old paradigm : the Belgian "expansion laws" (1959-1988)}

The old paradigm of regional policy can be applied to Belgium from the 1950s. In 1959, the "expansion laws" were implemented, the Belgian variant of regional policy (Buyst, 2011; Cabus, 1995). The aim was to promote industrial development and to equally distribute economic prosperity over Belgium through investment policies and an active policy for the development of industrial estates (Cabus, 2002). The policy scheme of the "expansion laws" largely included a broad range of subsidies and tax incentives often targeted towards private companies in designated "development regions"(Barca et al., 2012 ; Buyst, 2011; Heremans, 1983; Wolfe, 2011). Next to financial support, the scheme developed well-equipped manufacturing and industrial sites intended to attract foreign investment to regions facing structural unemployment. The industrial policies of the "expansion laws" targeted a limited set of sectors which were regarded as "national sectors", these included coal, steel, shipbuilding, textile and glass industries.

The main driver for Belgian regional policy was the remarkable differential pattern of economic development between Flanders and Wallonia. From the beginning of the 19th century Wallonia strongly industrialized due to its rich deposit of coalfields and further development of related steel, glass, zinc and machine-building industries (e.g. export of locomotives and other transport equipment) (Boschma, 1999 ; Buyst, 2011). The region in the south of Belgium was one of the most important manufacturing centers in Europe until the First World War. At the end of the 1950s profitability problems in the Belgian coal mining industries gave rise to an enormous blow for the raw materials based economy of Wallonia. The closing down of various mines resulted in massive job losses.

From the 1960 on, Flanders developed a considerable economic lead and surpassed Wallonia in per capita GDP (Albrechts \& Swyngedouw, 1989 ; Buyst, 2011). The Treaty of Rome (1957) strengthened European integration and created a new market, which in turn attracted multinational companies mainly to Flanders. The port areas in Flanders saw a large inflow of foreign direct investment in e.g. oil refineries and petrochemical facilities. Furthermore, the expansion of industries like metal processing and the production of consumer goods compensated for the decline of traditionally strong sectors (e.g. agriculture, textiles and clothing) in all the Flemish provinces. As a result, the economic structure of Flanders modernized and export performance strengthened.

In 1973, the oil-crisis started a structural economic crisis in Europe. The "national sectors" struggled to stay competitive in a globalizing market (Buyst, 2011; Heremans, 1983). Due to the large weight of these traditional sectors in the economic structure and rigidities in the regional labour markets, Wallonia went through a process of painful adjustment from the 1970s on. Policies were often responding to industrial decline and had a "backing losers" approach. For example, the Belgian government budgeted in the period 1979-1982 more than 85 billion Belgian francs (around 2,3 billion euro) for the "national sectors". This budget had to compensate for the location disadvantages of the underperforming regions. The contributions of the "expansion laws" remain a matter of debate (Buyst, 2012 ; see e.g. De Brabander et al., 1992, p. 142). 


\section{Towards a Flemish regional innovation policy $(1980-\ldots$ )} Belgium, a process of regionalization started in the 1970s (Voets \& De Rynck, 2006). This process resulted in the creation of Regions and Communities in Belgium. A second state reform in 1980 transferred certain competencies in industrial and economic policy to the Regions. This gave the Flemish Region the opportunity to develop own instruments for development, like investment incentives, economic expansion schemes, public industrial initiatives, applied scientific research and education and training programs (Capron \& Meeusen, 2000). But industrial policy concerning the "national sectors" mining, steel, textiles, glass and shipbuilding remained a federal competence till the state reform in 1988-1989 (Buyst, 2011). Further, this institutional reform transferred competences regarding public works, export promotion and employment policy to the Regions. The Federal state reforms in the last decades strengthened the Regions continuously in competences and resources and made Belgium one of the most regionalized member countries of the OECD (OECD, 2010). Flanders can, according to Voets \& De Rynck (2006), in itself be considered as a "new state space" (Brenner, 2004).

The first phase of deindustrialization and increasing competitive pressures in the 1980s spurred regions to upgrade their industrial basis (Dicken, 2007; Rodriguez-Pose \& Crescenzi, 2008). Regional industrial, economic and innovation policy started shifting subsequently towards endogenous concepts and emphasized a technologically oriented view of innovation. The policy object focused on the embedding of nascent high-tech sectors like microelectronics, biotechnology, new materials, chemical industry and the high-tech end of traditional industries in "regional growth poles". In 1983, at the time that the federal government still supported the old "smoke stack" industries, the first Flemish government initiated the "Third Industrial Revolution in Flanders" (DIRV) program aimed at the modernization of the regional economic structure by focusing on new science-based industries as biotechnology and microelectronics, increased cooperation between universities, entrepreneurs and the government and the promotion of entrepreneurship (Buyst, 2011 ; Larosse, 2005 ; Oosterlynck, 2011). In the university-town of Leuven, the establishment of the Interuniversity Microelectronics Centre (IMEC) further enhanced the "technology-push"-character of Flemish policy by targeting the research intensity of large companies and state-funded organizations. Furthermore, the newly established Flemish government launched a large-scale promotion campaign that included the international technology fair "Flanders Technology International" and the organization of technology transfer activities. At the end of the 1980s the strong growth performance of the Flemish Region, fuelled by a new wave of FDI in the chemical and automotive industry, undermined interest in regional economic policy.

From the 1990s on the Flemish government turned more and more to diffusion-oriented technology support policies which enhanced knowledge accessibility and absorption and the embedding of SMEs in regional innovation networks and systems (Hassink \& Klaerding, 2011; Lagendijk, 2011). Furthermore regional innovation policy realigned technology-oriented support and innovation-oriented objectives, attaching greater importance to university-generated knowledge (Ranga, Debackere \& von Tunzelmann, 2003). Different levels of government introduced science parks, innovation support 
agencies, technological aid schemes and technology transfer agencies to stimulate cooperation between universities and industry to the regional landscape (Wolfe, 2011).

Inspired by the successful story of Silicon Valley (Larosse, 2001) and academic literature on the spatial co-localization or "clustering" of small and medium-sized enterprises (e.g. Third Italy) and their potential for economic and innovation benefits (Audretsch \& Feldman, 1996; Porter, 1998), the Flemish government developed a top-down cluster policy (Goorden, 2005; Hertog et al., 2001). The government designated six clusters to encourage the formation of trans-sectoral platforms, but there was little interest for the specific kind of policy intervention from the relevant economic actors. From 1994, a bottom-up mechanism identified twelve platform projects in more mature industries, ranging from textile machinery and steel plate utilization, to more high-tech platforms, like digital signal processing, speech and language technology and product development techniques (Goorden, 2005). Several years later, in 1998, a new policy of "technology valleys" was implemented aimed at the creation of networks of high-tech firms, research centers, and educational and training institutions in emerging technology-driven sectors, with "Flanders Language Valley" as source of inspiration (Hertog, et al., 2001). This cluster policy was according to Hertog et al. (2001) "not well documented and took an approach which was too close to "picking winners' to win sufficiently broad political support". From the ten valley initiatives in preparation, only two materialized within the framework of the European structural funds.

30 At the end of the twentieth century, the European approach towards regional innovation policy got a more systematic character with the implementation of theoretical and conceptual ideas as Regional Innovation System (RIS) (Tödtling, 2010 ; Uyarra, 2010). Also Flanders took a step towards an innovation policy based on a systems approach (Larosse, 2005). In the 1999, cluster initiatives were structurally integrated in the so-called "Innovation Decree", which gave the Flemish government a legal framework to further expand the R\&D policy into a broader and more integrated perspective of innovation (e.g. inclusion of non-technological dimensions of innovation, university interfaces to promote spin-offs, new support measures for SMEs) but support to technological innovation remained central (Goorden, 2005). The policy provided for a number of instruments that could be used to encourage innovation along the whole innovation life cycle and at the network level. These instruments promoted more intensive interaction between research organizations (knowledge generation) and firms and intermediary organisations (knowledge exploitation), often in the form of collaborative projects (Tödtling, 2010).

31 An example of these instruments provided by the "Innovation Decree" are the "Centers of Excellence", which were introduced in 2002 and structurally embedded as "Competence Poles" in a legal framework in 2005. The Poles are demand-driven cluster networks geared towards specific industrial or service sectors like automotive (Flanders Drive), food industry (Flanders Food) and design (Flanders in Shape). Although some "Competence Poles" are very well integrated in the Flemish innovation and economic landscape, Larosse (2005) argues that the proliferation of "Competence Poles" in the last decade showed the limits of the "knowledge-push" strategy where a mix of bottom-up and top-down policies provided no strategic direction and guidance for economic development in Flanders. In 2011, the Flemish government proposed its "New Industrial Policy" (NIB) with a focus on spearhead domains and a targeted cluster policy approach managed through a new kind of "strategic governance" (Vlaamse Regering, 2011). Main 
concepts in this new policy are the transformation of value chains, lead-companies and open innovation.

\section{Subregional development policy (1988- ...)}

Although the Belgian "expansion laws" and the newly acquired STI-policy implicitly had a regional component, explicit regional development policy only came about in Flanders at the end of the 1980s (Cabus, 1995, 2002). The regionalization process, with Flanders as an ambitious actor, created a "multi-layered subregional arena" where different arrangements increased the institutional complexity but also the potential for territorial governance (see e.g. Tubex et al., 2005). As Voets \& De Rynck (2006, p. 906) point out: "Flanders is both an arena and a governmental tier".

Verhetsel \& Witlox (2001) outline initiatives that structure the specific Flemish regionaleconomic policy : namely the establishment of Regional Development Agencies (GOM) in the 1970s and the interweaving of European regional policy and Flemish regionaleconomic policy. The transformation of European structural funding in 1988 acted as a catalyst for the implantation of Flemish regional policy (Cabus, 2002 ; Van der Wee, 1991; Verhetsel \& Witlox, 2001). The need for an extension of special attention for particular Flemish regions came out of the ascertainment that some socio-economic lagging regions ineffectively engaged in structural funding. The first regional development "Impuls"program (1990-1994) focused on 8 lagging regions, mostly complementing Objective 2 or $5 \mathrm{~b}$ eligible-regions (Cabus, 1995). Even though the governance aspect of the program was embryonic, it triggered bottom-up initiatives and mediated between the regions and the Flemish government (Cabus, 2002).

From 1994, subregional platforms were set up to "contribute to an organized and enduring collaboration between actors in a subregion to stimulate economic growth, revenues and employment" (Voets \& De Rynck, 2006, p. 909). The platforms are regarded by Cabus (2002) as "development coalitions" comprised out of local public (local governments) and private actors (e.g. trade unions and employers' organizations) with additional partners such as the Flemish Public Employment Service (VDAB), NGOs and local companies. One of their objectives is the setup of a strategic "regional pact" every six years, stimulating bottom-up initiatives and act as an interface between the subregions and the Flemish regional government. Cabus (1995) saw in the mid-1990s three important shifts in the establishment of sub-regional platforms and the analysis of their "regional pacts" :

- A shift in content: regional policy shifted from a purely regional-economic approach through expansion-support, over a mainly regional-economic approach through European structural funding, towards an approach where more attention lies on the endogenous growth potential of regions.

- A shift in spatial orientation : towards the inclusion of "strong regions" in regional policies.

- A shift in governance: from a top-down towards a more multi-level and bottom-up responsibility for drafting and implementing regional policies.

These shifts can be interpreted as the first seeds of a move towards a "place-based" approach for regional development in Flanders. A turning point came in 2004 when the Flemish government approved three decrees that aligned the coherence in subregional socio-economic policy. A first decree established the sub-regional partnership Regional Socio-economic Committees (RESOC and SERR) as an "advisory and consulting structure" 
or "strategic director" for regional development. A second decree established the Provincial Development Agencies (POMs), the former GOMs, and a third decree coordinated the task setting and policy implementation arrangements of the various actors.

Regional development in Flanders has seen, as indicated by Cabus $(1995,2005)$ a turn towards the endogenous potential of all regions in Flanders. The "regional pacts" of the subregional platforms include a comprehensive development project for the subregions, often linked with Flemish priorities. Furthermore, under impulse of the ERDF, the governance changed towards a more bottom-up and multi-level approach of drafting and implementing policies. Although some characteristics of a place-based approach are present in the subregional platforms, we also see characteristics of the "old paradigm" in the regional development policies of Flanders For example the focus on infrastructure projects that have to guarantee the accessibility and mobility of the subregion. Some authors argue that the goal to come to a more integrated subregional economic development failed, among other reasons due to the relative powerlessness of the platforms (Cabus, 2002). Moreover, there is no real significant decentralization in terms of competences and resources at the subregional level (Voets \& De Rynck, 2006). Furthermore regional aid declined in significance in Flanders. Various designated areas for regional support have over time been cut back, due to the lowering of ERDF-funds and the continued focus on competitiveness and growth of the Flemish government. In the period 2007-2013 regional aid cutbacks were around $20 \%$ compared to the previous programming period (Yuill, Ferry, Vironen, McMaster \& Mirwaldt, 2008), although that urban policy got more policy attention and resources in the last decades (De Decker, Kesteloot, De Maesschalck \& Vranken, 2005 ; Loopmans, 2007).

\section{A smart specialisation strategy : Flanders in Action $(2006-\ldots)$}

From the beginning of the 2000s a more strategic framework and integrated approach towards regional policy and STI-policy began to arise (Yuill et al., 2008). In line with the Europe 2020 Strategy, various strategic initiatives to guide socio-economic development are undertaken by regional governments around Europe (e.g. "Flanders in Action"). Moreover, some regions already developed a smart specialisation strategy, for example Navarra (Spain), Emilia Romagna (Italy), West Midlands (UK) and Skane (Sweden), although the territorial strategies were not named like that (Ortega-Argiles, 2012). Also the "Flanders in Action" program is considered to be a "smart specialisation" strategy (European Commission, 2010 ; Ortega-Argiles, 2012).

In 2006 the Flemish government started the "Flanders in Action" program (ViA), a strategic framework for socio-economic development. The set target of this programmebased strategy is becoming a "top 5 knowledge intensive region in Europe by 2020" (VRWI, 2011). Flanders continued to focus on competitiveness. Science, technology and innovation policy is perceived as playing a vital role across various themes and policy sectors. The current ViA-strategy is the outcome of a process of ongoing policy development. Various major plans were introduced from 2001 on. Namely the Vilvoorde Pact (2001), Innovation Pact (2003) and the Flemish Innovation Policy Plan (2005), each of which addresses specific aspects of factors influencing innovation (Ortega-Argiles, 2012). 
The Flemish Reform Program (2011) shows the integration of Europe 2020 goals within the Flemish policy framework. The document illustrates the presence of multi-level dynamics between the European Union and the Flemish regional level.

For the priority-setting with regard to the STI policies of the ViA-program, the Flemish Science Policy Council (VRWB) was commissioned to carry out a large-scale foresight Delphi-study (VRWI, 2011). The foresight study identified six cluster domains: (1) transport, (2) ICT and health care services; (3) health care and treatment; (4) new materials, nanotech, and the processing industry ; (5) ICT for socio-economic innovation ; and (6) energy and environment for the service sector and processing industry. In a follow-up study these clusters were further elaborated on to form 10 breakthrough initiatives that strategically guide Flemish policy development (e.g. New Industrial Policy). The Flanders in Action framework further strengthens an approach based on the development of "innovation crossroads" where societal challenges and strengths of the Flemish economic, industrial and knowledge base come together.

\section{Conclusion}

Profound changes reshaped the competitive advantage of regions. The changing role of the region in economic development gave rise to significant changes in various sectoral policies targeting these regions (e.g. in research, innovation, regional development, industrial and economic policy).

This paper tries to illustrate the on-going paradigm shift in regional policy. Therefore we described in general terms the case of the northern Belgian region of Flanders. The new paradigm "gradually come about through independent changes taking place in different contexts and cultures" according to Barca (2009, p. 4). In Flanders, this new paradigm is already strongly developed when looking towards a broadly defined regional policy concept. This includes regional innovation, industrial and economic policies which all have a territorial impact, though with a weak "place-based" operationalization.

From the 1970s on the policy object of Flemish innovation, industrial and economic policy targeted not only the underperformance of particular regions but started to focus on competitiveness and the endogenous growth of the subregions of Flanders. Regional governments throughout Europe were influenced by academic literature on clusters, innovative milieux and networks and the economic performance of regions like Silicon Valley and the Third Italy. This led to the decline of more traditional policy instruments and put an instrumental focus on technology and innovation.

Flanders developed an innovation-oriented regional policy which targeted technology development and absorption capacity and moved on towards a systematic view on innovation at the end of the 1990s. In the mid-2000s policy formulation got a more important role with the embedding of various initiatives in the broader multisector and multilevel governance context of "Flanders in Action" (Lagendijk, 2011). The role of science, technology and innovation is perceived as vital in this strategic framework.

Considerable attention is given to "smart specialisation strategies" at the European and regional level, the subregional level often tends to be forgotten in this discussion. Although having limited competences and resources, also the subregional (and local) level plays a substantial role in regional development policies in Flanders. Even in the absence of an explicit territorial focus in the "Flanders in Action" program, various 
subregional actors are involved in the development or implementation of "smart specialisation"-initiatives. We can conclude that at this moment the paradigm shift in regional policy is not universal, both that the "old" and "new" paradigms co-exists in Flanders (Bachtler \& Yuill, 2001 ; OECD, 2010).

Future research will target the multi-level aspects of these subregional "smart specialisation" initiatives. Furthermore a more thorough evaluation of the "Flanders in Action" program will help to appreciate the actual impact of this framework on regional development in Flanders.

\section{BIBLIOGRAPHY}

ALBRECHTS L. \& SWYNGEDOUW E. (1989), “Regionale planning en ontwikkeling : exponenten van maatschappelijke ontwikkeling”, Ruimtelijke planning, 23, 40.

AUDRETSCH D. \& FELDMAN M. (1996), "R\&D spillovers and the geography of innovation and production", American Economic Review, 86, 3, pp. 630-640.

BACHTLER J., WISHLADE F. \& YUILL, D. (2001), "Regional Policy in Europe after enlargement", Regional and Industrial Policy Research Paper, 44.

BACHTLER J., WISHLADE F. \& YUILL D. (2003), “Regional policies after 2006 : Complementarity or conflict?", Regional and Industrial Policy Research Paper, 51.

BACHTLER J. \& YUILL D. (2001), "Policies and strategies for regional development : a shift in paradigm ?", Regional and Industrial Policy Research Paper, 46.

BARCA F. (2009), An Agenda for a Reformed Cohesion Policy-Independent Report, Brussels, European Commission.

BARCA F., MCCANN P. \& RODRIGUEZ-POSE A. (2012), “The Case for Regional Development Intervention : Place-Based Versus Place-Neutral Approaches”, Journal of Regional Science, 52, 1, pp. 134-152.

BOSCHMA R. (1999), "The rise of clusters of innovative industries in Belgium during the industrial epoch", Research Policy, 28, pp. 853-871.

BOSCHMA R. (2005), "Role of proximity in interaction and performance : Conceptual and empirical challenges", Regional Studies, 39, 1, pp. 41-45.

BRENNER N. (2004), New state spaces : urban governance and the rescaling of statehood, Oxford, Oxford University Press.

BUYST E. (2011), “Continuity and change in regional disparities in Belgium during the twentieth century”, Journal of Historical Geography, 37(3), pp. 329-337.

BUYST E. (2012), "Why was Belgium so late in adopting Keynesian ideas and devising regional development policies?", VIVES-Discussion paper, 27, pp. 1-18.

CABUS P. (1995), "Vlaanderens Regionaal Beleid op Nieuwe Wegen”, Planologisch Nieuws, 15(3), pp. 175-201. 
CABUS P. (2002), “Governance in Flanders' regional policy : subregional platforms as development coalitions", Belgeo, 3, pp. 277-294.

CAF (2010), Desarollo Local : Hacia un Nuevo Protagonismo de las Ciudades y Regiones, Caracas, Corporacion Andina de Fomento.

CAPELLO R. \& NIJKAMP P. (2009), Handbook of regional growth and development theories, Cheltenham, Edward Elgar.

CAPRON H. \& MEEUSEN W. (2000), The national innovation system of Belgium, Heidelberg, New York, Physica.

CHARBIT C. (2011), “Governance of Public Policies in Decentralised Contexts : The Multi-level Approach", OECD Regional Development Working Papers.

CRESCENZI R. \& RODRIGUEZ-POSE A. (2011), "Reconciling top-down and bottom-up development policies", Environment and Planning A, 43, 4, pp. 773-780.

DE BRABANDER G., VERVOORT L. \& WITLOX F. (1992), Metropolis : over mensen, steden en centen, Leuven, Kritak.

DE DECKER P., KESTELOOT C., DE MAESSCHALCK F. \& VRANKEN J. (2005), "Revitalizing the City in an Anti-Urban Context : Extreme Right and the Rise of Urban Policies in Flanders, Belgium", International journal of urban and regional research, 29, 1, pp. 152-171.

DG REGIONAL POLICY (2011), “2020 : The Role of Regional Policy in the Future of Europe”, Panorama Magazine, 39.

DICKEN P. (2007), Global shift : mapping the changing contours of the world economy, New York, Guilford Press.

DOGARU T., VAN OORT F. \& THISSEN M. (2011), “Agglomeration Economies in European Regions : Perspectives for Objective 1 Regions", Tijdschrift voor Economische en Sociale Geografie, 102, 4, pp. 486-494.

EUROPEAN COMMISSION (2010), Communication from the Commission: Regional Policy contributing to smart growth in Europe 2020 (COM 2010 - 533).

EUROPEAN UNION (2007), Treaty of Lisbon Amending the Treaty on European Union and the Treaty Establishing the European Community.

FORAY D. (2009)," Understanding Smart Specialisation", in PONTIKAKIS D. KYRIAKOU D. \& VAN BAVEL R. (Eds.), The Questions of R\&D Specialisation : Perspectives and Policy Implications, Seville, European Commission/Joint Research Centre, pp. 14-24.

FORAY D. (2011), Smart Specialisation : From Academic Idea to Political Instrument, the Surprising Destiny of a Concept and the Difficulties Involved in its Implementation, Paper presented the Conference "European Integration Process in the New Regional and Global Settings", Warsaw. FORAY D., GODDARD J., GOENAGA X., LANDABASO M., MCCANN P., MORGAN K., MULATERO F. (2011), RIS 3 Guide, Seville, European Commission/Joint Research Centre.

GARCILAZO J., MARTINS J. \& TOMPSON W. (2010), Why Policies May Need to be Place-Based in Order to be People-Centred, retrieved from http://www.voxeu.org/article/why-policies-may-need-beplace-based-order-be-people-centred

GILL I. (2010), Regional Development Policies : Place-Based or People-Centred ?, retrieved from http:// www.voxeu.org/index.php?q=node/5644 
GOORDEN L. (2005), Innovation policy and technology assessment in Flanders, Brussels, Flemish Institute for Science and Technology Assessment.

GRABHER G. (1993), “The weakness of strong ties : the lock-in of regional development in the Ruhr area," in GRABHER G. (Ed.), The embedded firm, London, Routledge, pp. 255-277.

HASSINK R. \& KLAERDING C. (2011), “Evolutionary approaches to local and regional development policy, in PIKE A., RODRIGUEZ-POSE A. \& TOMANEY J. (Eds.), Handbook of Local and Regional Development, London, Routledge, pp. 139-149.

HASSINK R. \& SHIN D. (2005), "The restructuring of old industrial areas in Europe and Asia”, Environment and Planning A, 37, 4, pp. 571-580.

HEREMANS D. (1983), “Financieringsaspecten van een gewestelijke industriepolitiek”, Tijdschrift voor Economie en Management, 28, 3, pp. 295-331.

HERTOG P., REMOE S. (2001), Innovative clusters : drivers of national innovation systems, Paris, OECD. HOOGHE L., MARKS G. \& SCHAKEL A. (2010), The rise of regional authority : a comparitive study of 42 democracies, London, Taylor \& Francis.

LAGENDIJK A. (2011), "Regional innovation theory between theory and practice", in ASHEIM B., BOSCHMA R., COOKE P. (Eds.), Handbook of Regional Innovation and Growth, Cheltenham, Edward Elgar, pp. 597-608.

LAROSSE J. (2001), ICT Clusters in Flanders : Co-operation in Innovation in the New Network Economy; Flemish Contribution to the Focus Group on "cluster Analysis and Cluster-based Policy", IWT-Vlaanderen.

LAROSSE J. (2005), “Towards a third-generation innovation policy in Flanders : policy profile of the Flemish Innovation System", in OECD (Ed.), Governance of Innovation Systems : Case studies in innovation policy, Paris, OECD, pp. 333-356.

LOOPMANS M. (2007), "From SIF to City Fund : a new direction for urban policy in Flanders, Belgium", Journal of Housing and the Built Environment, 22, 2, pp. 215-225.

MANZELLA G. \& MENDEZ C. (2009), The turning points of EU cohesion policy, Glasgow, University of Strathclyde.

MCCANN P. (2008), "Globalization and economic geography : the world is curved, not flat", Cambridge Journal of Regions, Economy and Society, 1, 3, p. 351.

MCCANN P. \& ORTEGA-ARGILES R. (2011), “Smart Specialisation, Regional Growth and Applications to EU Cohesion Policy", Economic Geography Working Paper, University of Groningen. OECD (2009), How Regions Grow Trends and Analysis, OECD.

OECD (2010), Regional Development Policies in OECD Countries, OECD.

OOSTERLYNCK S. (2011), "The political economy of state restructuring and the regional uneven transition to after-Fordism in Belgium", in HUYSSEUNE M. (Ed.), Contemporary centrifugal regionalism : comparing Flanders and Northern Italy, Brussel, Koninklijke Vlaamse Academie van België voor Wetenschappen en Kunsten, pp. 83-94.

ORTEGA-ARGILES R. (2012), Economic Transformation Strategies : Smart Specialisation Case Studies, University of Groningen.

PIKE A., RODRÍGUEZ-POSE A. \& TOMANEY J. (Ed.), (2010), Handbook of local and regional development, New York, Routledge.

PORTER M. (1998), On competition, Boston, Harvard Businesss School Publishing. 
RAINES P. (2001), “The cluster approach and the dynamics of regional policy-making”, Regional and Industrial Policy research paper, 47.

RANGA L., DEBACKERE K. \& VON TUNZELMANN N. (2003), "Entrepreneurial universities and the dynamics of academic knowledge production : A case study of basic vs. applied research in Belgium", Scientometrics, 58, 2, pp. 301-320.

RODRIGUEZ-POSE A. \& CRESCENZI R. (2008), “Mountains in a flat world : why proximity still matters for the location of economic activity", Cambridge Journal of Regions Economy and Society, 1 , 3, pp. 371-388.

SMART SPECIALISATION PLATFORM (2012), retrieved from http://ipts.jrc.ec.europa.eu/ activities/research-and-innovation/s3platform.cfm

THISSEN M. \& VAN OORT F. (2010), "European Place-Based Development Policy and Sustainable Economic Agglomeration”, Tijdschrift voor Economische en Sociale Geografie, 101, 4, pp. 473-480.

TÖDTLING F. (2010), "Endogenous approaches to local and regional development policy”, in PIKE A., RODRÍGUEZ-POSE A. \& TOMANEY J. (Eds.), Handbook of local and regional development, New York, Routledge, pp. 333-343.

TUBEX S., VOETS J. \& DE RYNCK F. (2005), Een beschrijvende analyse van ruimtelijk-ecologische en socio-economische arrangementen in Vlaanderen, Gent, SBOV.

UYARRA E. (2010), "What is evolutionary about "regional systems of innovation" ? Implications for regional policy", Journal of evolutionary economics, 20, 1, pp. 115-137.

VAN DER WEE B. (1991), "Het Regionaal Beleid van de Europese Gemeenschap”, Ruimtelijke planning, 26, pp. 1-40.

VERHETSEL A. \& WITLOX F. (2001), "Ruimtelijke structuurplanning en strategische streekplanning : ruimte en economie in de knoop ?", Ruimte en Planning : Tijdschrift voor Ruimtelijke Planning, Stedenbouw en Huisvesting 21, 1, pp. 23-31.

VLAAMSE REGERING (2011), Witboek Nieuw Industrieel Beleid, Brussel.

VLAAMSE REGERING (2011), Vlaams Hervormingsprogramma Europa 2020, Brussel.

VOETS J. \& DE RYNCK F. (2006), “Rescaling territorial governance : A Flemish perspective”, European Planning Studies, 14, 7, pp. 905-922.

VRWI (2011), Advies 153 : De $1 \%$ norm voor O\&O - invulling groeipad, Brussels, VRWI.

WALENDOWSKI J. (2011), “Policies and Processes of Smart Specialisation : Realising New Opportunities", Regional Innovation Monitor Thematic Paper, 2, Brussels, Technopolis Group.

WINTJES R. \& HOLLANDERS H. (2010), “The Regional Impact of Technological Change in 2020”, Report to the European Commission, Brussels, DG Regional Policy.

WOLFE D. (2011), Place-based Development Policy: Implications for North America, Paper presented at the International Seminar on Regional Innovation Policies, Lund University.

WORLD BANK (2009), World Development Report 2009 : Reshaping Economic Geography, Washington DC, World Bank.

YUILL D., FERRY M., VIRONEN H., MCMASTER I. \& MIRWALDT K. (2008), “New Policy Frameworks, New Policy Approaches : Recent Regional Policy Developments in the EU and Norway", EoRPA Paper, 8, 1, University of Strathclyde, EPRC. 


\section{ABSTRACTS}

Due to the changing role of "the region" in economic development, it appears that policies targeted towards regions underwent significant changes in objectives, geographical scope, governance and policy instruments. This paper challenges three main questions related to recent changes in regional policy. Firstly, what are the fundamental characteristics of the "old" regional policies? Secondly, did the "old" paradigm evolve into a new paradigm of regional policy? And if yes, how did these changes materialized and what characteristics where affected? Lastly, we consider how these changes were integrated in Flemish regional policies.

Il semble qu'en vertu de l'évolution du rôle de la "région" en matière de développement économique, les politiques tournées vers les régions ont subi d'importants changements en termes d'objectifs, d'envergure géographique, de gouvernance ou encore d'outils politiques. Cet article se penche sur trois questions majeures liées aux évolutions récentes caractérisant cette politique régionale. En premier lieu, quelles sont les particularités des “anciennes" politiques régionales? Ensuite, l'“ancien" paradigme a-t-il évolué vers un nouveau paradigme dans ce domaine? Et, dans ce cas, comment ces changements se sont-ils matérialisés et quels sont les aspects qui ont été touchés? Enfin, nous examinons comment ces évolutions ont été intégrées dans les politiques régionales menées en Flandre.

\section{INDEX}

Keywords: Flanders, paradigm change, place-based approach, regional policy

Mots-clés: Flandre, changement de paradigme, approche axée sur le lieu, politique régionale

\section{AUTHORS}

\section{TIES VANTHILLO}

University of Antwerp, Faculty of Applied Economics, Department of Transport and Regional Economics, Prinsstraat 13-SB.403, B-2000 Antwerpen, Corresponding author, ties.vanthillo@ua.ac.be

\section{ANN VERHETSEL}

University of Antwerp, Faculty of Applied Economics, Department of Transport and Regional Economics, ann.verhetsel@ua.ac.be 